\title{
Organizational Justice Analysis on Employees Satisfaction and Performance in Faculty of Education Universitas Negeri Surabaya
}

\author{
Gunarti Dwi Lestari \\ Universitas Negeri Surabaya \\ Surabaya, Indonesia \\ gunartilestari@unesa.ac.id
}

\begin{abstract}
Influencing is the core of educational leadership. The ability to influence people is a necessary 'strength' and 'way', so one has the power and creative in creating a way to move towards achieving goals. The justice of the institution to its each employee has an effect on the job satisfaction and performance of the employee. The formulation of the problem in this research was whether there was an influence of organizational justice to job satisfaction and performance of Education Faculty toward Unesa staff. The research was conducted by correlational quantitative approach with variance analysis. Based on the research conducted and the data analysis results obtained, it can be concluded that the organizational justice variables that include procedural, distributive and interactional justice gave influence to job satisfaction and performance of Education Faculty toward Unesa employees. Organizational justice carried out by institution leader gave big influence to job satisfaction and performance of Education Faculty to Unesa staff.
\end{abstract}

Keywords: Organizational Justice Analysis; Employee Satisfaction; Performance;

\section{INTRODUCTION}

The power of education involves the capacity of one party (agent) to influence the other (target) [8, 9]. The ability which is seen in the 'agent' affects on a person or set of people as a target. By contrast, agent may also be individuals or groups of people who demonstrate their potential ability for 'mastering' behaviors and attitudes. Then, this power brings up leadership. Leadership is essentially a way or effort to influence others in achieving goals. Influencing is at the core of educational leadership. To be able to influence a person is necessary 'power' and 'way'. So, a leader who has the power and creative in creating a way in moving others to achieve goals.

Human Resources is a very important capital for educational institutions, it needs to be managed in a professional and fair $[10,11]$. Human resource as a human capital asset or capital intellectual asset has a contribution for educational institution which will simultaneously give influence and bring the institution benefits. This is because the human resources for educational institutions is the 'main capital' in carrying out its activities $[12,13]$.

Human Resources owned by the Education Faculty of Unesa staff are 55 people, consisting of: 1 head of administration staff, 4 vice staff administration, 44 administrative staff, 1 driver, and 5 security officers (Data Education Faculty Data 2016). As Frederick Herzeberg [2] pointed out, it is important to treat employees with workplace needs and treated fairly in accordance with their respective duties and authorities. Every position like head of administration staff, vice staff administration, administrative staff, equipment staff, maintenance staff, cleaning service staff has different duties and responsibilities, need of different work place and selfactualization. The fair (proportional) treatment of the institution to all Education Faculty Unesa employees is the success key to achieve excellent service performance.

Organizational justice is very important factor in determining the behavior and performance of Education Faculty of Unesa employees. This will affect job satisfaction and work climate of all employees of Education Faculty of Unesa. Fair treatment to each employee in accordance with the duties and authority from the institution leader impacts on attitudes and employee performance behavior.

Academic test and psychological ability for employees is one way to determine the ability and potential of each employee. Next, it will be performed an arrangement in the form of 'mutation' from one part in another part of the work environment Education Faculty Unesa. This often leads to employee 'dissatisfaction'. So it needs careful research to give an analysis on the treatment of Leader (Organizational Justice) to job satisfaction and employee performance at Education Faculty of Universitas Negeri Surabaya.

Based on the above background, it can be formulated research problems as follows.

1. Is there any effect of organizational justice on job satisfaction and employee performance at Education Faculty of Universitas Negeri Surabaya?

2. How is the effect of organizational justice on job satisfaction and employee performance at Education Faculty Universitas Negeri Surabaya?

This research is limited to the influence of organizational justice variable on job satisfaction and employee performance at Education Faculty of Unesa working environment, so there are other variables that are not included in this research. 


\section{METHOD}

This research used quantitative approach with explanatory research type which explained the causal relationship between independent variable with dependent variable $[6,14,15]$. The causal relationship between the variables was carried out through the hypothesis test of the influence of organizational justice on job satisfaction and employee performance of Education Faculty to Unesa staff. The research was conducted in the working environment of the Faculty of Education (FIP) Universitas Negeri Surabaya (Unesa) situated in Unesa Lidah Wetan campus, Lakarsantri district, Surabaya. The populations in this research were all employees of FIP Unesa Surabaya, as many as 53 employees. While the samples were the entire employees of 53 employees who got fair and unjust treatment from the leadership, both civil servants and non-civil servants. Data collection was performed by some techniques as follows; 1) questionnaire, 2) interview, and 3) observation.

Validity test is used to measure the level of correlation between each score in the questionnaire and the total amount. If the value has positive correlation then the measurement of this variable will be valid.

\section{RESULTS AND DISCUSSION}

The focus of this study was to determine the effect of organizational justice on employee satisfaction and employee performance Education Faculty Unesa as an institution engaged in services. Higher education institutions engaged in public service that must have the power of excellent service. Good services include the accuracy, speed, and comfort provided by employees to the customers of higher education. The better the services provided, the more satisfaction customer got.

Similarly, employees' satisfaction in working to provide services for customers associated with the behavior of leaders who provide justice for employees to each other in accordance with their proportions. Justice perceived by employees relates to job satisfaction and performance of employees at Education Faculty of Unesa by fulfillment of employees' rights.

Based on the observation of the employees in interaction and feel 'leader's behavior' justice is very influential on the effort to provide services for customers' institutions of Education Faculty of Unesa. Observations were made to the head of administration staff and vice staff administration. Ordinary employees and non-civil servants provided a picture of the influence of organizational justice on job satisfaction and employee performance in institutions of Education Faculty Unesa.

Some critics, feedbacks and comments from employees on the organizational justice in treating them are part of the effort to improve the institution in management. So, the fair treatment of the organization to employees in getting things and providing sincere service for customers and employee performance are the keys to the success of the institution.
3.1 Effect of Organizational Justice on Job Satisfaction and Employee Performance

The test results simultaneously show that the organizational justice variables, namely procedural, distributive, and interactional justice significantly affect job satisfaction and employee performance in FIP Unesa. The result of the calculation of analysis of the effect of organizational justice on employee job satisfaction obtained the value of $F$ equal to 67,850 with significance level 0,000 (p $<0,05)$. On the other hand, the results of calculating the analysis of the effect of organizational justice on the performance of employees obtained the $F$ value of 77.542 with a significance level of $0.000(\mathrm{p}<0.05)$.

Organizational justice variables significantly influence job satisfaction while employee performance is influenced by the independent variables. Organizational justice will affect job satisfaction and employee performance in carrying out their work as the implementing element of service administration activities in Education Faculty of Unesa working environment. Justice perceived by employees is categorized well with good value. This happens because employees feel their rights are being noticed by the institution. This is in accordance with what Lind \& Tyler (1988) say about justice in which it is described as a social situation when norms of rights and worthiness are met. An employee's right is a compensation which an employee must receive after performing the duties imposed on him. Kerf (1996) states that the basic value of a justice is human dignity so that the basic principles of justice are an appreciation of the dignity and rights attached to it.

Justice perceived by employees generally affects job satisfaction and employee performance which they get. Based on the regression model obtained, it can be seen that the increasing elements of organizational justice will also increase job satisfaction and employee performance. The model gives an explanation that organizational justice variable gives positive effect to employee job satisfaction (67.85) and employee performance (77.542). This is related to the behavior of leaders in giving fair treatment to employees in work and career development. Such fair behavior has been shown that it has an effect on job satisfaction and employee performance. Based on the calculation results, it can be compared that the effect of organizational justice on employee performance is higher or greater. The greater or higher the fair treatment in the institution, the greater or higher the performance shown by employees in completing their duties and obligations.

Organizational justice according to Greenberg (in Fendi S, et al, 2005) refers to employee perceptions of justice in organization. Organizational justice generally focuses on two

(2) main issues, i.e. the employee's response to the income received and the procedure used to earn the income. Different income with one another is often not seen from the work given. This means that the workload with income received is not worth / balanced. So, it brings sense of unfair experienced by employees. Similarly, the procedure used in the framework of 'equity' of justice to all employees 
Lind \& Tyler [5] generally describes justice as a social situation when the norms of rights and eligibility are met. Organizational justice is a social situation of rights and obligations which running well. The obligations of every employee in the position and job responsibilities as well as the right to a comfortable funds and 'salary' are well met. So, the employee satisfaction in work can be felt, which will simultaneously impact on performance (optimization of good work) in any employee.

Mc Farlin \& Sweeny [7] divide organizational justice into two: procedural justice and distributive justice. This means that procedural justice is a proper treatment to employees through inter-intrapersonal relationships so that organizational procedures run well and bring a sense of comfort in work. Leaders create the conditions of relationships and working procedures as best as possible to eliminate the rigid 'formalities' to be flexible. Similarly, distributive justice, is justice in distributing work and welfare. Equity of work to each employee ensures work according to their potential and expertise. Every employee has their own duties and responsibilities. Thus, the distribution of welfare will be obtained equally among employees. Procedural justice (procedural justice) in organizational decision making has shown an influence and behavioral reaction. The consequences of procedural justice include the following; (1) commitment to the organization, (2) the desire to remain in the organization, (3) the behavior of the organization member, (4) trust in the boss, (5) satisfaction with the decision result, (6) compliance with the decision, (7) effort in task, and (8) performance.

The unfair treatment of organizations given to employees has an impact on people's discomfort at work. The organization's distributive justice to each employee on the same level of salaries, facilities, and profits is the 'thing' that is often the trigger for conflict / problems. The feeling that the unfairly treatment of organization is in the form of salary and profit distribution. Therefore, research on distributive justice is needed to know the extent to which the influence of each variable on customer satisfaction. Fendy et al (2005: 129) mention several aspects related to distributive justice as follows. First, it lies in the value used in the organization. Justice and injustice lie in the value it embraces. Values are 'guidelines' on every organization's decisions regarding salaries, facilities and benefits. Second, it lies in the process of formulating values into rules. Thus, there is agreement of one principle of justice that is arranged and agreed so that problems do not arise. How to translate values into mutually agreed rules. Third, it lies in the implementation of the rule that lies in the implementation of agreed rules. If the rules are not implemented in part or in whole, it means that there is no distributive justice within the institution. Based on some experts opinions related to justice that is divided into procedural justice and distributive justice with various indicators that build it.

The theory of justice (Gibson, 1985) states that employees compare their efforts with benefits received or benefits received in return for other employees in the same situation. This theory is based on the assumption that employees are motivated by the desire to be treated fairly in the work, individual organizations to get the appropriate rewards from the organization. The main standards in fairness include payroll, assigned duties, time taken into account and working teams so that things considered into a reference in providing justice for employees.

Davis \& Newstrom (1985) point out that there is a very close relationship between rewards that employees think should be accepted. Employees have the right to compare the rewards they receive to those received by others. So, it creates jealousy on employees who feel not treated fairly. Fair treatment from the leaders of the scope of work Education Faculty Unesa provide a significant and positive impact on job satisfaction and employee performance.

Job satisfaction can be seen in the attitudes shown by employees in the work, which is happy in doing the task, seriousness in doing the task assigned, committed to doing the task, and feel comfortable in the work environment, 'work' in the present position. Other aspects of being responsible in the work, doing the task creatively, the attitude of trust to the leadership of the faculty, agree with the program and decisions taken by the leader, satisfied with the treatment of leadership, and trying to complete the task in accordance with the time specified. These aspects of job satisfaction indicate that organizational justice done by the leader is well noticed, and vice versa.

Employee performance can be seen in the work from the attitude of the employees in doing the task on time, teamwork in completing the task, can achieve the target set by the institution, the attitude in the career in the position of work, responsible for work, timely presence, neat appearance, and have initiative in work.

All scores of research variables influence organizational justice on job satisfaction and employee performance including good category. This proves that organizational justice is able to positively affect job satisfaction and employee performance in Education Faculty Unesa working environment. Justice that employees feel is in accordance with what they want, so give a positive influence on employee job satisfaction and employee performance.

\section{CONCLUSION}

Based on the performed research and the results of data analysis obtained, it can be concluded that the organizational justice variables that include procedural, distributive and interactional justice give influence to job satisfaction and performance of Education Faculty Unesa employees.

\section{REFERENCES}

[1] K Davis, and J W Newstrom, Human behavior at work: Organizational behavior, McGraw-Hill, 1989

[2] G Desler, Manajemen Sumber Daya Manusia, jilid I, Jakarta: PT Prenhalindo, 1997

[3] T R Tyler and E A Lind, "Understanding the nature of fraternalistic deprivation", in Relative deprivation: Specification, development, and integration, pp 44-68, 2002

[4] A S Keraf, Pasar bebas keadilan \& peran pemerintah: telaah atas etika politik ekonomi Adam Smith. Kanisius, 1996 
[5] E A Lind and T R Tyler, The social psychology of procedural justice Springer Science \& Business Media, 1988

[6] E W Sugiyono, Statistika penelitian dan aplikasinya dengan SPSS 10.0 for Windows, Bandung: Alfabeta, 2002

[7] P D Sweeney, and D B McFarlin, Workers' evaluations of the "ends" and the "means". An examination of four models of distributive and procedural justice. Organizational Behavior and Human Decision Processes, Vol. 55, pp 23-40, 1993

[8] G Yukl, Leadership in organizations (7th ed.), Upper Saddle River, NJ: Prentice Hall, 2010

[9] L C Fred, "Leadership versus management: a key distinction-at least in theory", in International Journal of Management, Business, and Administration, Vol. 14 No. 1, 2011
[10] S A Scott and D W James, "Integrated Manufacturing and Human Resource Management: A human Capital Perspective", in Academy of Management Journal, Vol. 35 No. 1, 1992

[11] B E Sandra and L M Lisa, "Human-capital investments and productivity", in The American Economic Review, Vol. 86 No. 2, pp 263-267, 1996

[12] S W Theodore, "Investment in Human Capital", in The American Economic Review”, Vol. 51 No. 1, pp 1-17, 1961

[13] S A Scoot and L P David, "The human resource architechture: towardto a theory of human capital allocation and development", in ACAD Management REV, Vol 24 No. 1, pp 31-48, 1999

[14] A Daniel, "Using SPSS to understand research and data analysis", in Psychology Curricular Materials, Book 1, 2014

[15] C Larry and J Burke, Educational Research: Quantitative, Qualitative, and Mixed Approaches Third Edition, London: Sage Publication, Ltd., 2008 